\title{
Reflections on the Kitchen Accord ${ }^{1}$
}

\section{Roy J. Romanow, PC OC QC.*}

It is, indeed, an honour to be a part of the $\mathrm{Pa}$ triation Negotiations Conference, sponsored by the Centre for Constitutional Studies, exploring the method and substance of Canada's most significant constitutional development since Confederation.

I want to say a word about why this conference matters. Canada's search to understand its dynamics and its values was an important step in national self-awareness. To my mind, patriation reflects both a point of constitutional maturity and a point of sophisticated intergovernmental process.

A nation lives, in significant part, by the ways in which it understands its constitution's purposes and principles. We most certainly do not make a mistake when we take time to get beneath and beyond the constitution's particularistic and often contingent provisions, and look for the meaning that it has for its own political community - the sense of nation that propels its makers into agreement. I believe that it is by understanding the context in which our Constitution was made that we can come to understand how that Constitution bears on our present context - in the place and time in which, and at which, we now stand. When we honour our past, we enrich our present.

So, why was this constitutional reform so important? And, what did those who participated in the processes by which it was formed, believe to be its value to our national development?

No one should put ahead, in the ranking of importance, the value to Canada of patriation - the putting in place of a domestic constitution that stood for Canada's fully realized and formalized capacity of self-determination. It is what sovereign nations place the greatest stock in, and, since the 1926 Balfour Declaration by Great Britain, full patriation had been Canada's aim and its hope. This project was interrupted by depression, war, social reconstruction, the demands of the modern activist state and, finally, by the great difficulty of finding a national consensus. In all these years, Canada both yearned for this sign of its sovereignty and experienced the near impossibility of obtaining the necessary national agreement to achieve it.

At the end, we did not, in fact, find the full national agreement that we wanted. Without unanimity there will, forever, be an element of failure in the history of our nation building - a serious chink in the edifice of a self-determining nation. However, it is a chink that, in my view, is better than the endless scenarios of divisiveness and conflict that confronted us on the afternoon of November 4, 1981, if no agreement, whatsoever, had been reached. Total failure would have stood as Canada's deep failure as a nation - and as its shame.

I recognize that this is a highly contentious assessment, but I maintain that one cannot understand the dynamics of November, 1981 without grasping the strength of the imperative on Canada to find in itself the capacity to set its own destiny.

The deals made were certainly imperfect and the process by which they were made was sometimes unfair. Still, the full realization of our nationhood in the 1981-82 constitutional reforms was an achievement whose national value is beyond measure. 
Other important constitutional achievements attended the November 5, 1981 agreement: an amending formula that enabled constitutional patriation; the constitutionalization of rights; and a commitment to fund public services and public government equally. And, may I dare to mention Saskatchewan's own agenda priority - a better constitutional regime for the taxation and regulation of provincial natural resources.

There were other failures in that agreement, besides the one already mentioned. These include the failure to entrench gender equality so that it could not be abridged by legislative action, the failure to give more substantial constitutional recognition of Aboriginal rights, the failure to reform the Senate and to give explicit constitutional protection to the Supreme Court. Thank goodness that, before too many weeks following the November 5 accord had passed, at least some of these gaps were addressed and corrected.

The point I want to make is that, in 1981, the nation, through its political leadership, sought to find a way to complete the construction of Canada and to adopt important modern elements of liberal democratic constitutionalism the recognition of human and minority rights, the instrumentalities for effective public social care, and the recognition of Indigenous peoples' rights. This was a heady constitutional agenda and it equipped Canada for its future. We are right to celebrate this achievement.

My part in this Conference is to revisit the role of the so-called "Kitchen Accord". The most obvious starting point is to dispel the unbelievable claim, considering the momentous and hard-fought statecraft of the previous decade, that the new Constitution was actually designed quickly, in a side kitchen in the Conference Centre and that the terms of patriation were crafted on two hand written sheets of notepaper.

Let me elaborate on this obvious disjunction in two ways. First the 1982 Constitution did, in fact, flow from an accord, but it was not solely the Kitchen Accord - the better name for which - but not the name that history, in its whimsy, has chosen to give it -might be the
"Kitchen Proposals". The 1982 Constitution was based on a signed accord entered into by 10 of Canada's First Ministers. It is they who had led constitutional discussions since 1978, and it is they who represented their political communities. It is they who, in their best judgment, decided that the best interests of Canada and its people would be served through formal agreement to the November 5 Constitutional Accord. The Kitchen proposals were, as Ron Graham has described, in his book The Last $A c t^{2}$, and as I, Howard Leeson and John Whyte described 27 years earlier, ${ }^{3}$ one significant piece in the jigsaw of Canadian patriation politics.

The second point I want to make about the relationship between the complex process of high politics that produced the Constitution Act, 1982, ${ }^{4}$ and the encounter in the kitchen to sketch out terms of a possible compromise, is that both aspects - complex statecraft and quick tentative agreements for a possible deal - reflect the same basic underlying reality. That reality is that the process for making the 1982 Constitution was a process of extended teamwork, based on trust among most of the participants.

First, let me discuss the teamwork amongst governmental delegations. In my political career, I have been involved in many intergovernmental policy processes, but not one of them has generated the same level of political commitment, dedication of resources and the building of such skilled and talented teams of officials, analysts and lawyers. I can speak best of Saskatchewan's team, but we were not unique. Saskatchewan did have a good team, but so did the other governments, including, naturally, the exceptional federal team. In Saskatchewan, our working group was led, with tremendous effect, by Howard Leeson and accompanied by brilliant analytic work provided by Bob Weese. On the legal side, we had a wonderfully sophisticated Deputy-Attorney General, Dick Gosse and, in my view, three brilliant constitutionalists James MacPherson, John Whyte and George Peacock.

Naming these people, I confess, tells you little. So let me add this: the process, over more than three years, entailed hundreds of meetings, hundreds of documents, hundreds of drafts. 
There was no way to meet the demands of the process other than sending officials and lawyers to meetings, often with uncertain mandates and with little time for consultation and briefing. In my experience, my officials and every other jurisdiction's officials did a job that was at the very top of the game in terms of their commitment, effort, communication and judgment.

Good public administration depends on integrity and intelligence. I saw both of these every hour and every day through three years of constitutional negotiation. But the quality in all this that most stands out is trust. I trusted them and I know that they trusted Allan Blakeney and me and with that trust came confidence and good judgment.

And, it is this idea of trust that I want to focus on as I describe the overall process of intergovernmental relations. As a minister in this process, I came to know the other ministers Dick Johnston, Jean Chretien, Garde Gardom, Roy McMurtry, Horace Carver, and so forth. Our close interactions with each other engendered confidence in each other's good faith, judgment, sense of humour, and integrity. Who knows what comes first - friendship or trust but both developed. They became both the keel and the rudder of the constitutional reform process.

The Premiers, too, formed a similar bond, even in the face of differences, such as their political parties, constitutional visions, intellectual styles - theorist or pragmatist - and, even, differences in their negotiating alignment as the process grew more intense after October 1980.

So, permit me to describe the background to this federal-provincial dynamic more fully. The Continuing Committee of Ministers on the Constitution (CCMC) was the important catalyst to eventual success. It should serve as a Canadian model of intergovernmental negotiation, discussion, and deliberation. It was the product of Prime Minister Trudeau's proposals for patriation and constitutional amendment, as set out in 1978 in "A Time for Action," and the 14 matters identified by the provinces as the topics for study. Both initiatives overlapped in many respects and it was quickly resolved that a working committee of federal-provincial ministers and advisors would be charged with the responsibility of recommending so-called "best efforts drafts" for each of the said matters. As it happens, the chair of the Annual Premiers Conference in 1978 was Saskatchewan's Allan Blakeney. And, as practice dictated, the Saskatchewan minister named by Premier Blakeney would serve as the provincial co-chair. That provincial co-chair was me.

Even to this day, I am uncertain as to whether or not there were precedents for this kind of structure, which, in other federal-provincial meetings, was normally chaired by an appropriate federal minister. This is of little consequence because what matters is that a robust round of discussions of detailed proposals on each of the assigned items ensued.

We all recognized that much of the work had been done earlier, particularly with regard to the Victoria Conference of 1971 and the proposed Charter of Rights and Freedoms. As well, various proposals for the amending formula had also been previously discussed and debated.

As we all know, of course, the urgency of the 1978 process was the result of the election of René Levesque's PQ government in Quebec in 1976.

There were several new issues on the "order paper" after 1978. These were, in no particular order, new recommendations on an amending formula, new categories of constitutional change, such as natural resources, fisheries, and family law, mobility rights, greater emphasis on resolving outstanding Aboriginal issues and, of course, the matter of an entrenched Charter of Rights and Freedoms.

Although it was modeled, somewhat, on previous constitutional efforts between 1968 and 1971, I submit that the CCMC was a unique institution. There was great continuity, both as to individuals who were involved and the issues. There was a thorough and intense participation by professional civil servants from both orders of government and, even, qualified advisors from outside the civil service. Typically, subcommittees, each studying one of these particu- 
lar 14 matters identified by the First Ministers, would meet for a good portion of a day and, thereafter, all the ministers and officials met together to review and to debate the progress, if any, in arriving at "best efforts drafts."

All of this meant that a very complex and interconnected agenda was the subject of a great deal of scrutiny and understanding by both the politicians and the advisors, up to and including the First Ministers Conference in the fall of 1980. Over the many meetings, ministers and no doubt officials, fully understood the range of possibilities with respect to the issues. Perhaps, even more importantly, trust and an unspoken desire to achieve success both grew, even when there were divergent views.

It was complicated, to be sure. The CCMC worked in the atmosphere of heightened Western Alienation, centered on resources jurisdiction, and, of course, the most important issue of all - the possible independence of Quebec. These two forces alone meant that all of us were working in uncharted territory. Still, growing feelings of respect, determination to succeed, and thorough study of options by advisors created a kind of a bond and a will to succeed by all of us who were there at the time. I suspect the same could be said of the First Minister of the day, as well.

As I write, I think I can hear your justifiably impatient thought waves. "Romanow," these thoughts are saying, "what on earth has this to do with the Kitchen Proposals?"

My answer is this: this period of working together, seriously and respectfully over a long period, on a policy project of great importance to our nation, meant that at the crucial moment - a moment of collapse, despair and failure, a moment when the Prime Minister thought it best to walk away from the talks, call in the press corps and declare our national failure, but also a moment when the cooler heads of Peter Lougheed, Allan Blakeney and Bill Davis recognized that there was still a possibility for compromise - the project was saved not by the substantive brilliance of anyone or anybody's correct understanding of Canada's constitutional needs, and not by miraculously discovering the perfect constitution, but by relationships - relationships that were built on friendship and, more importantly, trust. It was these good relationships and trust that kept some of us looking for the common bridge that we knew had to be there. Jean Chretien, Roy McMurtry, and I met in the kitchen at the critical moment, not because we had any answers - or even a great deal of hope - but because our friendship and our mutual sympathy for each other's anxieties and fears simply compelled us to continue searching for a constitutional plan that would satisfy enough interests, on terms that we thought did not break our trust with each other, did not break our trust with national principles and most importantly, perhaps, did not break our trust with our principles and with our colleagues.

A sense of positive reaction followed. That was enough to produce a delay in declaring failure and enough from which to fashion further suggestions. The delay was for an evening only but an evening in which the long investment in respectful relationships between premiers, ministers and officials within delegations and, especially between delegations produced a dividend. Certainly, the key catalyst for the evening's coalescence were the Kitchen Proposals/Accord but others - certainly Premier Peckford, for one - brought ideas (and, of course, conditions) to those evening meetings in Premier Blakeney's hotel suite. In any event, in due course, the premiers, their ministers and their officials, exploring together and working together, had a plan that they felt the Prime Minister would see the fairness of. In fact he did, although, as Ron Graham writes in The Last Act, this perception was undoubtedly aided by strong bargaining on the part of Premier Davis. ${ }^{6}$ But that, too, in its way, was a product of a trusting relationship. Davis had been a loyal supporter of the Trudeau plan, at great cost to his own relationships within the country and, no doubt, within Ontario. His position forcefully delivered to the wavering, reluctant Prime Minister was owed respect by the Prime Minister and, ultimately, that is exactly what it was given.

People sometimes say that constitutionmaking is like sausage making - something you 
do not want to watch. But, for my part, I want to see it, I want to remember it. I want to celebrate it and, most of all, I want to honour it and to honour all those fine people who worked together with a common hope for their nation - the premiers, the ministers, the officials, the drafters, the lawyers, the academics, the journalists, and the citizens who came to Parliament or who stood on the steps of the Legislatures in Edmonton and Regina on cold November days. Most importantly, are the people, in all parts of Canada (yes, in Quebec too), who chose to accept our new Constitution and to participate in a nation with the constitutional principles by which we are all now governed.

And, I honour also today's Canada, where constitutionalism is the central element of our political way of life. I think that the events of November, 1981, helped Canada find its maturity and they helped shape our political integrity.

Others can make their own conclusions as to what impact, the so-called "Kitchen Accord" had on what was the eventual agreement revealed on Thursday November 5. I will only cite Ron Graham's conclusion in The Last Act. Graham writes: "What the three ministers [Romanow, Chretien and McMurtry] did accomplish, according to Allan Blakeney, was to set down in writing for the first time the terms the federal government might be ready to accept. That was crucial. ... Whether Lougheed and Davis were aware of it not, the Kitchen Accord was the foundation upon which Blakeney would build a deal later that evening. ... The Kitchen Accord may not have been the final settlement, but it came very close. ... its three godfathers were not under any illusion that their scribbles added up to a done deal."

\section{Notes}

* Senior Fellow in Public Political Studies at the University of Saskatchewan. Associated with the Johnson-Shoyama Graduate School of Public Policy. Hon. Romanow as appointed Minister of Intergovernmental Affairs in 1979 and was one of the key players in the federal-provincial negotiations that resulted in the Constitutional Accord and the Canadian Charter of Rights and Freedoms in 1982. He served as Premier of Saskatchewan from 1991-2001.

1 This article is based on a speech delivered at The Patriation Negotiations Conference, organized by The Centre for Constitutional Studies, University of Alberta, Edmonton, Alberta, November 3 to 5, 2011. I am grateful to John D Whyte for his assistance in the preparation of this paper.

2 Ron Graham, The Last Act: Pierre Trudeau, the Gang of Eight, and the Fight for Canada, (Toronto: Allen Lane Canada, 2011) at 190-198 [Graham].

3 Roy Romanow, John Whyte and Howard Leeson, CANADA...Notwithstanding: The Making of the Constitution, 1976-1982 25th Anniversary Edition, (Canada: Thomson Carswell, 2007) at 207-215.

4 Being schedule B to the Canada Act 1982 (UK), 1982, c11.

5 Parliament, "A Time for Action: Toward Renewal of the Canadian Federation" by Pierre Elliott Trudeau in Sessional Papers No 303-4/62 (1978).

6 Graham, supra note 2 at 189, 194, 209.

7 Graham, supra note 2 at 194. 